\title{
Deltamethrin resistance in the codling moth (Lepidoptera: Tortricidae): inheritance and number of genes involved
}

\author{
JEAN-CHARLES BOUVIER* , ROBERT BUĖS, THOMAS BOIVIN, \\ LILIANE BOUDINHON, DOMINIQUE BESLAY \& BENOÎT SAUPHANOR \\ I.N.R.A., U.M.R. Ecologie des Invertébrés, Site Agroparc, 84914 AVIGNON Cedex 09, France
}

\begin{abstract}
The inheritance of deltamethrin resistance in Cydia pomonella (L.) has been investigated by crossing a resistant (Rv) and a susceptible (Sv) strain, derived from a population collected in south-eastern France in 1995. Deltamethrin resistance was suspected to be under the control of a $k d r$-type allele and an enhanced mixed-function oxidase ( $\mathrm{mfo}$ ). $\mathrm{F}_{1}$ and $\mathrm{F}_{2}$ progenies were therefore tested through doseresponse and enzyme assays. Dose-response relationships indicated that resistance was inherited as an autosomal incompletely recessive $(D=-0.199)$ character, involving at least two genes. Enzyme measures suggested the contribution of 1.2 genes to the expression of mfo, with incomplete dominance $(D=0.460)$. Our results support the hypothesis of a polygenic response to deltamethrin selection in the Rv strain, including a major $k d r$-type allele with a minor effect of mfos. In the light of these findings, we consider the resistance in codling moth populations in south-eastern France as a product of an adaptive sequential selection process, occurring through the sequential addition of resistance genes.
\end{abstract}

Keywords: dominance degree, insecticide, polygenic resistance, resistance evolution, resistance mechanisms, selection.

\section{Introduction}

The acquisition of insecticide resistance has given one of the best opportunities to assess microevolution processes, partly because the nature of the selective agent is well identified and partly because, in response to this strong selection pressure, evolution is fast. As resistance reflects changes occurring in genotypic architecture of natural populations, a full understanding of the evolution of this phenomenon requires an accurate knowledge of its genetic basis (Roush \& Daly, 1990). But, beyond the evolutionary approach, genetic data constitute a necessary tool for investigating the mechanisms of resistance, and for predicting the behaviour of resistance genes, thus leading to a better estimation of resistance risks in populations. This may provide critical information in pesticide resistance management for the implementation of appropriate control decisions (Georghiou \& Taylor, 1986). The mode of inheritance of resistance has been well identified in a wide range of insect species such as mosquitoes (Halliday \& Georghiou, 1985; Raymond et al., 1987), aphids (Devonshire \& Field, 1991) and the

*Correspondence. E-mail: jbouvier@avignon.inra.fr diamondback moth (Tabashnik et al., 1992), but, to date, no data are available regarding the codling moth, Cydia pomonella (L.).

Chemical control failures for this species occurred in the early 1990s in orchards of south-eastern Europe (Waldner, 1993). Resistance to deltamethrin in this pest was first documented in 1995 (Bouvier et al., 1995). A study conducted on 14 French populations of codling moth revealed a correlation between resistance to deltamethrin and enhanced activity of mixed-function oxidases (mfos) (Bouvier et al., 1998). More recently, Brun-Barale et al. (2000) demonstrated the involvement of a sodium-channel mutation $(k d r)$ in deltamethrin resistance in $C$. pomonella. This mutation is known to play a major role in pyrethroid resistance in insects (Williamson et al., 1996). In this study, our aim was to investigate the inheritance of deltamethrin resistance in C. pomonella, and its potential consequences in terms of the population genetics in this species. We focused on the two following questions. (i) Which evolutionary scenario may have led to chemical control failure in south-eastern France? (ii) How would the selected resistance genes behave in natural codling moth populations? 
We used classical crosses between field-derived resistant and susceptible strains to evaluate the maternal effects, the degree of dominance, and the number of genes conferring resistance. This study was also expected to improve knowledge on mechanisms of resistance to deltamethrin in C. pomonella. Therefore, we propose a method based on measurement of enzymatic activity to determine the mode of inheritance of the enhanced mfo activity character.

\section{Materials and methods}

\section{Insect strains}

Codling moths were collected from the field in 1995 using corrugated cardboard trapping strips in an apple orchard at Les Vignères (south-eastern France) where deltamethrin failed to control moth populations. The resistant strain $(\mathrm{Rv})$ was derived from this sample of a wild population by selection for the first 10 generations with increasing doses of deltamethrin that induced $50 \%$ mortality, followed by a constant selection pressure $(2 \mathrm{mg} / \mathrm{L}$ of deltamethrin). The progeny of isolated pairs was tested with discriminating doses of chemical in order to determine the parental genotype (Sauphanor et al., 1998b). This procedure allowed the detection of susceptible adult pairs, whose progeny were used to build the susceptible strain (Sv). The two strains were kept by mass rearing on an artificial diet as described by Guennelon et al. (1981).

\section{Genetic crosses}

Adult codling moth were introduced into plastic cages ( $8 \mathrm{~cm}$ diameter, $5 \mathrm{~cm}$ high) with inner walls covered by thin white paper to receive the eggs, and containing sugared water as a food source. Twelve cages containing five pairs of adults were prepared for each cross and placed at $25^{\circ} \mathrm{C} \pm 1{ }^{\circ} \mathrm{C}, 40 \pm 10 \% \mathrm{RH}$ and under a 16:8 h (L:D) photoperiod. Larvae were reared in mass conditions identical to those of the parental strains. Virgin adults (less than 4-h-old) of the susceptible and the resistant strains were reciprocally crossed $\left(\mathrm{Sv}_{\text {female(f) }} \times \mathrm{Rv}_{\text {male }(\mathrm{m})} ; \mathrm{Rv}_{\mathrm{f}} \times \mathrm{Sv}_{\mathrm{m}}\right)$ to produce the $F_{1}$ hybrids. Because there was no evidence for sex-linkage (see Results), $F_{1}$ progeny from both reciprocal crosses were pooled and reared to adult stage for backcrossing to parental strains and intercrossing to produce the $\mathrm{F}_{2}$ progeny. The resulting backcross $\left(F_{1} \times R v\right)$ and the $F_{2}$ progeny were assessed in order to test the hypothesis of monogenic inheritance.

\section{Bioassays}

The susceptibility to deltamethrin of the Sv and the Rv strains and their different crosses was tested on newly hatched larvae (0-6-h-old). Fresh solutions of commercial insecticide were prepared in distilled water for each trial. Deltamethrin, or distilled water for the control, was sprayed on the surface of the diet prepared in $20 \times 20 \times 20 \mathrm{~mm}$ cups, using a Burgerjon tower (Burgerjon, 1956) at a dose of $1.7 \mathrm{mg} / \mathrm{cm}^{2}$. After air-drying of the diet for $2 \mathrm{~h}$, each larva was deposited on the treated surface. The cups were closed and kept at $25^{\circ} \mathrm{C} \pm 1{ }^{\circ} \mathrm{C}$, $40 \pm 10 \% \mathrm{RH}$ and under a 16:8 h (L:D) photoperiod. Mortality was recorded 4 days after treatment.

\section{Enzyme assays}

Total nonspecific mfo activity of 3-day-old larvae of the $\mathrm{Sv}$ and the Rv strains and their different crosses was determined by measuring 7-ethoxycoumarin-O-deethylation (ECOD) activity according to the procedure of De Sousa et al. (1995). The larvae were placed individually in wells of black microplates containing $100 \mu \mathrm{L}$ of $50 \mathrm{~mm}$ sodium phosphate buffer $(\mathrm{pH} 7.2)$ and $0.4 \mathrm{~mm}$ of ethoxycoumarin. The reaction was stopped after $4 \mathrm{~h}$ by adding $100 \mu \mathrm{L}$ of glycine buffer $\left(10^{-4} \mathrm{M}\right), \mathrm{pH} 10.4 /$ ethanol $(\mathrm{v} / \mathrm{v})$. In order to sediment the larvae in the wells, microplates were centrifuged at $2000 \mathrm{~g}$ for $30 \mathrm{~s}$ prior to and after the incubation of the enzymatic reaction at $30^{\circ} \mathrm{C}$. Wells receiving glycine buffer before incubation were used as blanks. Fluorescence was measured using a microplate reader (HTS 7000, Perkin Elmer) with $380 \mathrm{~nm}$ excitation, $465 \mathrm{~nm}$ emission filters and 50 for gain.

\section{Data analysis}

Mortality data from bioassays were corrected by natural control mortality using Abbott's formula (Abbott, 1925). Values of lethal concentration for $50 \%$ of individuals $\left(\mathrm{LC}_{50}\right)$ and of median mfo activity (mma) were calculated using a probit computer program (Raymond, 1985). They were considered significantly different when $95 \%$ confidence limits did not overlap. The degrees of dominance $(D)$ for both mortality and mfo activity were determined according to the method of Stone (1968) using the pooled data of the reciprocal $\mathrm{F}_{1}$ crosses:

$D=\left(\begin{array}{lll}2 X_{\mathrm{b}} & X_{\mathrm{a}} & X_{\mathrm{c}}\end{array}\right) /\left(\begin{array}{ll}X_{\mathrm{a}} & X_{\mathrm{c}}\end{array}\right)$,

where $X_{\mathrm{a}}=\log _{10}\left(\mathrm{LC}_{50}\right)$ or (mma) of the resistant strain, $X_{\mathrm{b}}=\log _{10}\left(\mathrm{LC}_{50}\right)$ or $(\mathrm{mma})$ of the pooled $\mathrm{F}_{1}$, and 
$X_{\mathrm{c}}=\log _{10}\left(\mathrm{LC}_{50}\right)$ or $(\mathrm{mma})$ of the susceptible strain. $D=1$ indicates complete dominance, $0<D<1$ incomplete dominance, $-1<D<0$ incomplete recessivity, and $D=-1$ complete recessivity. Dominance variances were calculated according to Bloch \& Wool (1994), where the standard deviation of resistance is given by the reciprocal of the probit regression slope (Finney, 1971):

$\sigma_{D}^{2}=4 / k\left[\left(\sigma_{\mathrm{b}}^{2}+\left(\begin{array}{ll}X_{\mathrm{b}} & X_{\mathrm{c}}\end{array}\right)^{2} \sigma_{\mathrm{a}}^{2} / k\right)+\left(\left(\begin{array}{ll}X_{\mathrm{b}} & X_{\mathrm{a}}\end{array}\right)^{2} \sigma_{\mathrm{c}}^{2} / k\right)\right]$

where $k=\left(X_{\mathrm{a}}-X_{\mathrm{c}}\right)^{2}$. Dominance level of survival at a given insecticide dose (in our case $0.75 \mathrm{~g} / \mathrm{L}$, the dose applied under commercial field conditions), referred to as effective dominance $\left(D_{\mathrm{ML}}\right)$, was calculated according to the formula as cited in Bourguet et al. (2000):

$D_{\mathrm{ML}}=\left(\begin{array}{ll}\mathrm{ML}_{\mathrm{F} 1} & \mathrm{ML}_{\mathrm{SS}}\end{array}\right) /\left(\mathrm{ML}_{\mathrm{RR}} \quad \mathrm{ML}_{\mathrm{SS}}\right)$,

where $D_{\mathrm{ML}}=0$ indicates complete recessivity, and $D_{\mathrm{ML}}=1$ complete dominance. The minimum number of independently segregating genes $(n)$ contributing to resistance was estimated according to Lande (1981):

$n=\left(\begin{array}{ll}\mu_{2} & \mu_{1}\end{array}\right)^{2} /\left(8 \times \sigma_{\mathrm{s}}^{2}\right)$,

where $\mu_{1}=\log _{10}\left(\mathrm{LC}_{50}\right)$ of the resistant strain, and $\mu_{2}=\log _{10}\left(\mathrm{LC}_{50}\right)$ of the susceptible strain. $\sigma_{\mathrm{s}}^{2}=\sigma_{\mathrm{B} 1}^{2}+$ $\sigma_{\mathrm{B} 2}^{2}-\left[\sigma_{\mathrm{F} 1}^{2}+0.5 \sigma^{2} \mathrm{~Sv}+0.5 \sigma_{\mathrm{Rt}}^{2}\right]$ (where $\sigma_{\mathrm{B} 1}^{2}, \sigma_{\mathrm{B} 2}^{2}, \sigma_{\mathrm{F} 1}^{2}$, $\sigma_{\mathrm{S} 1}^{2}$ and $\sigma_{\mathrm{R} 1}^{2}$ were the phenotypic variances of the backcrosses, $\mathrm{F}_{1}, \mathrm{~Sv}$, and Rt, respectively. We also used this method to estimate the number of genes involved in mfo activity. The null hypothesis of monogenic resistance was tested from mortality data of backcross progeny compared to theoretical expectations using the $\chi^{2}$-test (Tabashnik et al., 1992).

\section{Results}

\section{Inheritance of resistance to deltamethrin}

The $\mathrm{LC}_{50}$ of the $\mathrm{Rv}$ strain was 93.7 times greater than the $\mathrm{LC}_{50}$ of the Sv strain (Table 1). The dose-response of parental strains and of their $F_{1}$ were characterized by straight lines when bioassayed with deltamethrin, indicating that $\mathrm{Sv}$ and $\mathrm{Rv}$ strains were homogeneous for susceptibility and resistance to this insecticide, respectively (Fig. 1). The $\mathrm{LC}_{50}$ values of the reciprocal $\mathrm{F}_{1}$ crosses between the susceptible and the resistant strains did not differ significantly (Table 1). The null hypothesis of the parallelism test between the two probit regression lines of the reciprocal $F_{1}$ was not rejected at the $5 \%$ significance level $\left(\chi^{2}=1.59\right.$, d.f. $\left.=8, P=0.99\right)$. This equality suggested that sex linkage of resistance did not occur and that the genetic basis of the deltamethrin resistance was autosomal inheritance. Data of the reciprocal $F_{1}$ hybrids were combined. The degree of dominance of the $\mathrm{Rv}$ response to deltamethrin $(D)$ based on the $\mathrm{LC}_{50}$ data was $-0.199 \pm 0.039$, indicating an incompletely recessive resistance. The effective dominance, $D_{\mathrm{ML}}=0.480$, defined as the mortality of heterozygotes relative to that of both homozygotes at a given insecticide concentration applied in the field

Table 1 Response to deltamethrin of first instar codling moth for a homozygous deltamethrin-resistant strain (Rv), a susceptible strain (Sv) and various crosses

\begin{tabular}{|c|c|c|c|c|c|c|c|c|c|}
\hline $\begin{array}{l}\text { Strain } \\
\text { or cross }\end{array}$ & $n$ & $\begin{array}{c}\text { Control } \\
\text { mortality (\%) }\end{array}$ & $\begin{array}{c}\mathrm{LC}_{50} \\
\left(\mathrm{mg} \mathrm{L}^{-1}\right)\end{array}$ & $(95 \% \mathrm{CL})$ & $\begin{array}{c}\mathrm{LC}_{90} \\
\left(\mathrm{mg} \mathrm{L}^{-1}\right)\end{array}$ & $(95 \% \mathrm{CL})$ & Slope \pm SE & $\mathrm{HF}^{*}$ & $\begin{array}{l}\mathrm{LC}_{50} \\
\text { ratio }\end{array}$ \\
\hline $\mathrm{Sv}$ & 903 & 6.5 & 0.031 & $(0.026-0.036)$ & 0.134 & $(0.109-0.172)$ & $2.01 \pm 0.13$ & 1.96 & 1 \\
\hline $\mathrm{Rv}$ & 1000 & 7.7 & 2.905 & $(2.432-3.429)$ & 16.845 & $(13.417-22.242)$ & $1.67 \pm 0.11$ & 1.88 & 93.7 \\
\hline \multicolumn{10}{|l|}{$\mathrm{F}_{1}$} \\
\hline $\mathrm{Sv}_{\mathrm{f}} \times \mathrm{Rv}_{\mathrm{m}}$ & 670 & 4.2 & 0.177 & $(0.147-0.209)$ & 0.849 & $(0.667-0.158)$ & $1.88 \pm 0.15$ & 1.67 & 5.7 \\
\hline$R v_{f} \times S v_{m}$ & 439 & 0.0 & 0.214 & $(0.171-0.264)$ & 1.247 & $(0.916-1.894)$ & $1.67 \pm 0.15$ & 2.15 & 6.9 \\
\hline$F_{1} \ddagger$ & 1109 & 2.7 & 0.190 & $(0.166-0.218)$ & 1.012 & $(0.830-1.288)$ & $1.76 \pm 0.10$ & 0.73 & 6.1 \\
\hline $\mathrm{F}_{2} \S$ & 1110 & 4.3 & 0.088 & $(0.072-0.107)$ & 0.805 & $(0.616-1.117)$ & $1.33 \pm 0.08$ & 0.74 & 2.8 \\
\hline \multicolumn{10}{|l|}{ Backcross } \\
\hline $\mathrm{F}_{1} \times \mathrm{Sv} \boldsymbol{\top}$ & 830 & 4.6 & 0.054 & $(0.044-0.066)$ & 0.359 & $(0.272-0.509)$ & $1.55 \pm 0.11$ & 2.05 & 1.7 \\
\hline $\mathrm{F}_{1} \times \mathrm{Rv}^{* *}$ & 670 & 3.3 & 0.557 & $(0.438-0.690)$ & 3.829 & $(2.904-5.426)$ & $1.53 \pm 0.12$ & 0.90 & 17.9 \\
\hline
\end{tabular}

$* \mathrm{HF}$, the heterogeneity factor, is equal to $\chi^{2}$ divided by d.f.

$\dagger \mathrm{LC}_{50}$ of $\mathrm{Rv}$ and crosses divided by the $\mathrm{LC}_{50}$ of the Sv strain.

$\$$ Combined data from the two reciprocal crosses.

$\S\left(\mathrm{Rv}_{\text {male }(\mathrm{m})} \times \mathrm{Sv}_{\text {female }(\mathrm{f})}\right)$ and $\left(\mathrm{Sv}_{\mathrm{m}} \times \mathrm{R} \mathrm{v}_{\mathrm{f}}\right)$ pooled.

$\uparrow\left(\right.$ Pooled $\left.F_{1 \mathrm{~m}} \times \mathrm{Sv}_{\mathrm{f}}\right)$ and $\left(\mathrm{Sv}_{\mathrm{m}} \times\right.$ pooled $\left.\mathrm{F}_{1 \mathrm{f}}\right)$ combined. The pooled $\mathrm{F}_{1}$ corresponds to a combined reciprocal $\mathrm{F}_{1}$ hybrid.

$* *\left(\right.$ Pooled $\left.\mathrm{F}_{1 \mathrm{~m}} \times \mathrm{Rv}_{\mathrm{f}}\right)$ and $\left(\mathrm{Rv}_{\mathrm{m}} \times\right.$ pooled $\left.\mathrm{F}_{1 \mathrm{f}}\right)$ combined. 
Fig. 1 Responses of Cydia pomonella to deltamethrin. For each dose, the response is presented in terms of the percentage mortality observed in the susceptible (Sv) and the resistant (Rv) parental strain, in their pooled $F_{1}$ and the backcross $\left(F_{1} \times R v\right)$, as well as the percentage mortality expected for the backcross with the resistant parental strain calculated by assuming monogenic inheritance.

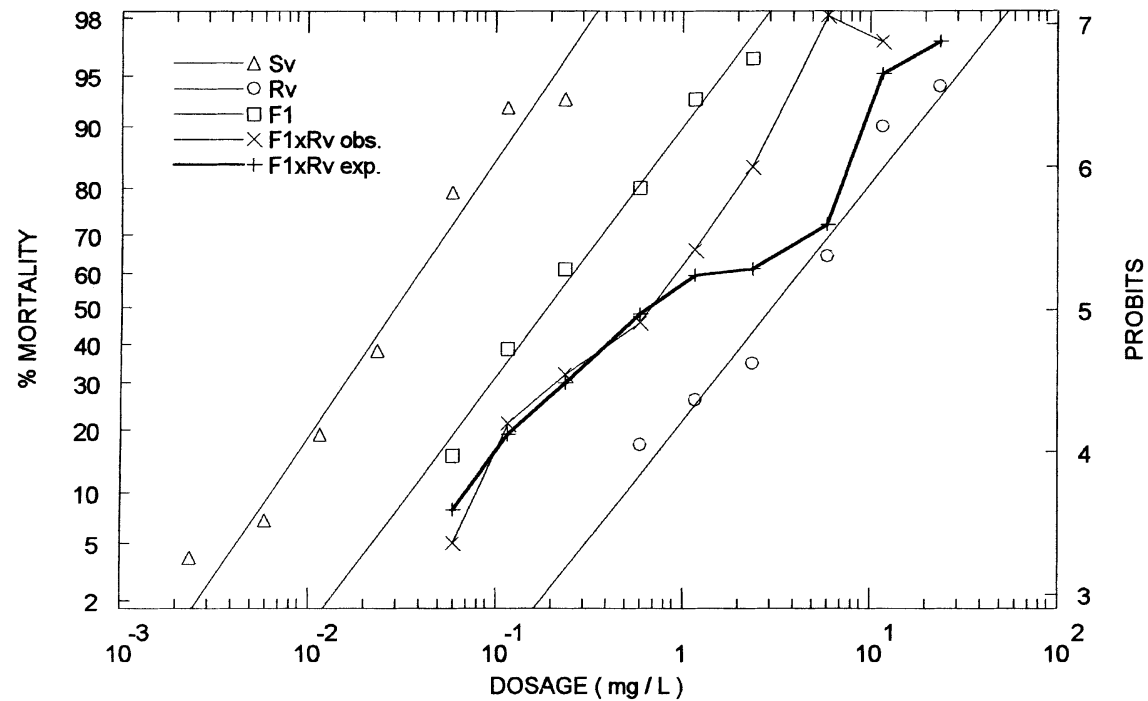

(Bourguet et al., 2000), indicates a codominant resistance. Observed mortalities of the backcross progeny with the resistant parent (Fig. 1) differed significantly from the expected theoretical curve based on the hypothesis of single factor resistance $\left(\chi^{2}=46.54\right.$, d.f. $=5, P=0.00$ ). We obtained similar results (Fig. 2) when the test of a monogenic model was performed on the $\mathrm{F}_{2}$ progeny $\left(\chi^{2}=95.88\right.$, d.f. $\left.=8, P=0.00\right)$. Deviations from expected mortality in the backcross and the $\mathrm{F}_{2}$ experiments suggested that more than one gene controlled the resistance to deltamethrin in the $\mathrm{Rv}$ strain. Using Lande's method (Lande, 1981) and the data on parental strains and reciprocal $F_{1}$, it was estimated that a minimum number of 2.2 genes are involved in deltamethrin resistance.

\section{Inheritance of the mfo activity involved in deltamethrin resistance}

Inheritance patterns of mfo activity were assessed from the same crosses as those used for studying deltamethrin resistance (Table 2). The mean activity level for the $\mathrm{Rv}$ strain was five-fold higher than that of the Sv strain and this difference was statistically significant at the $5 \%$ significance level (ANOva: $F=88.679, P=0.0001$ ). The degree of dominance estimated using the median mfo activities $(D)$ was 0.460 . This result indicated an incomplete dominance for the mfo activity, which was controlled by 1.2 genes.
Fig. 2 Responses of Cydia pomonella to deltamethrin. For each dose, the response is presented in terms of the percentage mortality observed in the susceptible $(\mathrm{Sv})$ and the resistant $(\mathrm{Rv})$ parental strain, in the $\mathrm{F}_{2}$, as well as the percentage mortality expected in the $\mathrm{F}_{2}$ calculated by assuming monogenic inheritance.

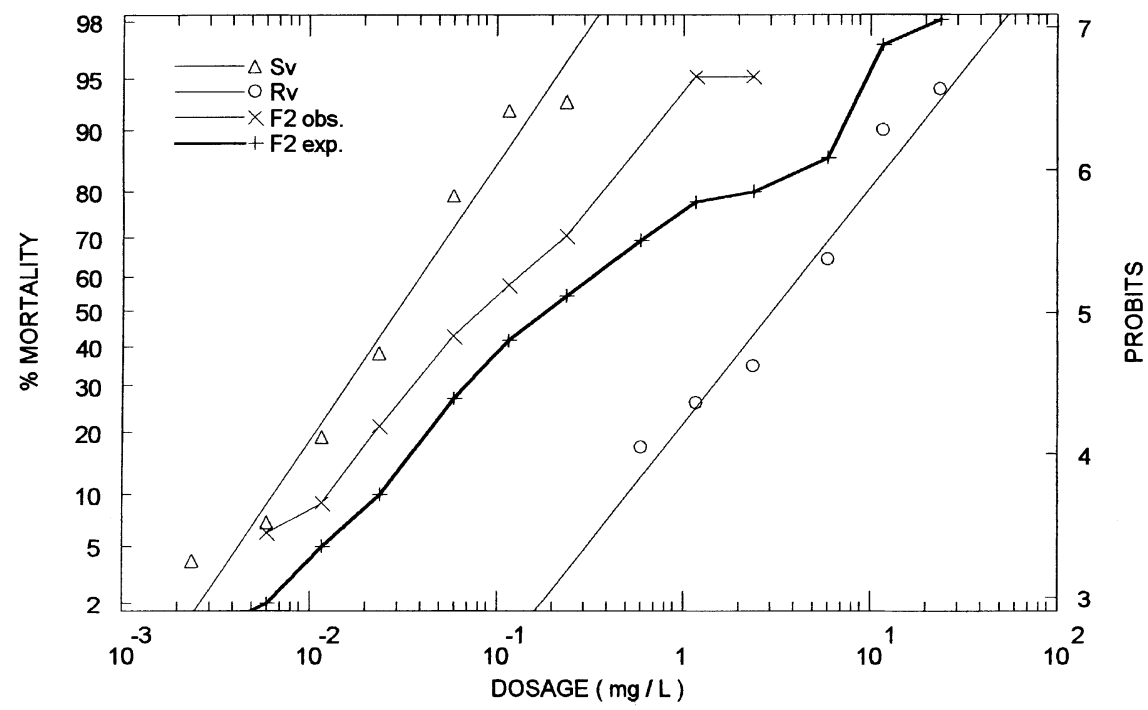

(C) The Genetics Society of Great Britain, Heredity, 87, 456-462. 
Table 2 Monooxygenase activity (ECOD) (measured in pg of $7 \mathrm{OH}$ formed/larva/min) in the parental strains ( $\mathrm{Sv}$ and $\mathrm{Rv}$ ) of the codling moth and various crosses involving these strains

\begin{tabular}{lccc}
\hline Strain & $n$ & Mean activity & Range of activity \\
\hline $\mathrm{Sv}$ & 48 & 17.24 & $1.15-44.83$ \\
$\mathrm{Rv}$ & 46 & 92.03 & $18.54-213.90$ \\
$\mathrm{~F}_{1}{ }^{*}$ & 51 & 58.48 & $3.58-216.02$ \\
$\mathrm{~F}_{2} \dagger$ & 44 & 49.80 & $5.95-171.22$ \\
Backcross & & & \\
$\mathrm{F}_{1} \times \mathrm{Sv} \ddagger$ & 47 & 32.27 & $0.00-150.43$ \\
$\mathrm{~F}_{1} \times \mathrm{Rv} \$$ & 49 & 68.35 & $5.95-163.06$ \\
\hline
\end{tabular}

* Combined data from the two reciprocal crosses.

$\dagger\left(\mathrm{Rv}_{\text {male }(\mathrm{m})} \times \mathrm{Sv}_{\text {female }(\mathrm{f})}\right)$ and $\left(\mathrm{Sv}_{\mathrm{m}} \times \mathrm{Rv}_{\mathrm{f}}\right)$ pooled.

$\ddagger\left(\right.$ Pooled $\left.F_{1 \mathrm{~m}} \times \mathrm{Sv}_{\mathrm{f}}\right)$ and $\left(\mathrm{Sv}_{\mathrm{m}} \times\right.$ pooled $\left.\mathrm{F}_{1 \mathrm{f}}\right)$ combined. The pooled $F_{1}$ corresponds to a combined reciprocal $F_{1}$ hybrid. $\S\left(\right.$ Pooled $\left.F_{1 \mathrm{~m}} \times R v_{\mathrm{f}}\right)$ and $\left(\mathrm{Rv}_{\mathrm{m}} \times\right.$ pooled $\left.\mathrm{F}_{1 \mathrm{f}}\right)$ combined.

\section{Discussion}

\section{Inheritance of deltamethrin resistance}

Our results indicated that resistance to deltamethrin in the Rv laboratory strain appeared to be controlled by at least two factors. Previous results obtained in the laboratory support the idea that several genes are involved in $\mathrm{Rv}$ resistance to deltamethrin. First, the involvement of enhanced mfo activity in the resistance of the Rv strain to deltamethrin was demonstrated by synergism assays with specific inhibitors and by in vivo metabolization of $\left[{ }^{14} \mathrm{C}\right]$ deltamethrin (Sauphanor et al., 1997). Second, we recently established the presence of a $k d r$ mutation in the sequence of one voltage-dependent sodium-channel gene of $\mathrm{Rv}$, i.e. leucine to phenylalanine replacement in the transmembrane segment IIS at position 1014 (Brun-Barale et al., 2000). A diflubenzuron-selected strain displaying comparable mfo activity to that found in the Rv strain (Sauphanor et al., 1997), but lacking the $k d r$ mutation (Brun-Barale et al., 2000), exhibited a 6.2-fold resistance to deltamethrin (Sauphanor et al., 1998a). The additional effect of the $k d r$ mutation in the $\mathrm{Rv}$ strain increased the resistance to deltamethrin to 93.7 -fold suggesting that the $k d r$ gene is the main mechanism of the resistance to deltamethrin in the $\mathrm{Rv}$ strain. Our results also show that deltamethrin resistance in the $\mathrm{Rv}$ strain was expressed as an incompletely recessive trait $(D=-0.199)$. Consequently, given that the mfo gene was incompletely dominantly inherited, we can assert that the major deltamethrin resistance factor in the Rv strain is incompletely recessive. The $k d r$ type resistance allele has already been shown to be incompletely recessive (Plapp, 1976; Halliday \& Georghiou, 1985) and inheritance of synthetic pyreth- roid mfo-type resistance has also previously been found to be monogenic with incomplete dominance in Helicoverpa armigera (H.) (Daly \& Fisk, 1992), as was the case in our Rv strain. Our results, i.e. the additional effect of $k d r$ and mfo, are in agreement with several genetic studies showing the involvement of these two mechanisms in pyrethroid resistance (Roush et al., 1986; McDonald \& Schmidt, 1987; Payne et al., 1988).

The occurrence of a segregation plateau at $60 \%$ mortality, rather than $50 \%$, in the expected results of the $\mathrm{F}_{1} \times \mathrm{Rv}$ backcross indicated that the $(\mathrm{RR} / \mathrm{RS})$ ratio was different from 1:1. According to Payne et al. (1988), divergence from a 1:1 segregation model may be due to the fact that: (i) interactions of the RR genome with an unlinked gene from the susceptible genetic background are lethal for a portion of the RR genotype, or (ii) resistance is not expressed in a portion of the $\mathrm{RR}$ genotype. However, we did not formally test these hypotheses in the present study.

\section{Pathway of acquisition of deltamethrin resistance in Cydia pomonella (L.)}

Adaptation of insect populations to chemical treatments is generally assumed to occur through a single-gene response (McNair, 1991; McKenzie \& Batterham, 1994). Because the doses applied in the field are designed to kill all individuals, selection is expected to act outside the original viability distribution of the population and to retain only single-locus alleles conferring high resistance levels. Hence, phenotypic variants carrying rare mutations conferring resistance to insecticide concentrations above those that eliminate $100 \%$ of the initial susceptible population have a selective advantage. This may clarify why monogenic responses to selection for insecticide resistance are common, although not universal (Roush \& McKenzie, 1987; Scott et al., 2000). However, resistance occurring in natural populations is often shown to imply several loci, but at an extremely limited number (Roush \& Daly, 1990). A shift from monofactoriality to multifactoriality may be associated with a subsequent addition of genes, as a consequence of an adaptive sequential selection process. Chlorpyrifos resistance in Culex pipiens (L.) provides an example of such an evolutionary scenario (Raymond et al., 1987). In this species, resistance was initially controlled by a single gene encoding detoxifying esterases, but has later included an altered acetylcholinesterase and enhanced mfos.

Acquisition of pyrethroid resistance in the codling moth may have followed an identical evolutionary pathway. At the early stages of chemical control of codling moth in south-eastern France, organophosphates were usually spread in apple orchards 
(Audemard, 1963). The use of several compounds related to this chemical group may be responsible for selection for a nonspecific detoxifying resistance mechanism, such as mfos, and conferring cross-resistance to pyrethroids. Selection of additional $k d r$-alleles by subsequent deltamethrin applications further weakened the effectiveness of pyrethroids through a higher combined resistance factor.

\section{Expected consequences for the rate of evolution of resistance}

The sequential acquisition of deltamethrin resistance may, in theory, influence the rate at which resistance evolves in codling moth populations. It is generally assumed that monogenic resistance is more likely to spread than is polygenic resistance. This has been supported by Hoy et al. (1980) and Roush \& Hoy (1981) for pyrethroid and carbaryl-resistant Metaseius occidentalis (N.) strains, showing that the mode of inheritance of pesticide resistance - polygenic $v s$. monogenic - can influence the rate of evolution of resistance frequency. This trend may be particularly pronounced if treatments are temporarily relaxed for a few generations or spatially alternated in mosaic structures, as dilution of resistance alleles occurs as a consequence of hybridization of polygenically resistant genotypes with susceptible genotypes (Roush \& McKenzie, 1987). The resulting phenotypes would not be sufficiently resistant to survive subsequent pesticide applications, especially if the major gene controlling resistance is expressed recessively; another factor contributing to the spread of resistance being the dominance of resistance alleles (Georghiou \& Taylor, 1986). However, it is critical to note that dominance is not an intrinsic property of an allele (Sved \& Mayo, 1970). Its expression typically depends on the chemical and on the dose applied, leading to the concept of effective dominance $\left(D_{\mathrm{ML}}\right)$ (Bourguet et al., 2000). If the dose applied in the field is high enough to kill heterozygous individuals, a dominant trait of resistance (as defined as the position of the mortality curve of heterozygotes relative to that of both homozygotes) turns into a functionally recessive character, as first underlined by Curtis et al. (1978). In the present work, estimation of both dominance and effective dominance indicated that deltamethrin resistance was incompletely recessive $(-0.199)$ and codominant $(0.480)$, respectively. However, $D_{\mathrm{ML}}$ predictions based on extrapolation of laboratory data to field conditions must be carefully considered with regard to their utilization in pest management strategies for two main reasons. Firstly, the range of concentrations that establishes dominance may differ between laboratory and field populations (Roush \& Daly, 1990) as a consequence of variability of mortality curves of the three genotypes between laboratory and field conditions. Secondly, because the effectiveness of residual applications is expected to decline due to chemical degradation during the control period, the resistance level expressed in heterozygotes could then remain high enough to allow survival. For example, the $k d r$ mutation became fully dominant in expression under low pyrethroid concentrations in houseflies (Denholm et al., 1990). In south-eastern France, deltamethrin is still efficient on benzoylurea-resistant codling moth field populations, in which mfos displaying the same activity as our $F_{1}$ had been selected (Sauphanor et al., 1998a). Moreover, deltamethrin recommendations include an overkill factor which ensures population control even under variations between the dose applied and the dose received by the insect (probit analysis provided by laboratory experiments showed that the dose applied in the field induced $70-80 \%$ mortality for homozygous resistant individuals). According to these data, we believe that the $k d r$-type allele may be expressed in the field as a recessive trait. Assuming that the determinism of resistance to pyrethroids in field populations and in our laboratory $\mathrm{Rv}$ strain is similar, one would thus expect that pyrethroid resistance development may be theoretically delayed under appropriate control strategies that would favour dilution of resistance alleles by enhanced flow of susceptible alleles and by periodic relaxation of selection pressure.

\section{Acknowledgements}

The authors wish to thank Cindy Morris for helpful improvement of the English in the manuscript, and Carole Caranta for critical comments.

\section{References}

Аввотт, w. S. 1925. A method of computing the effectiveness of an insecticide. J. Econ. Entomol., 18, 265-267.

AUDEMARD, H. 1963. La lutte insecticide contre la zeuzère (Zeuzera pyrina L.). Essais complémentaires de 1962. Phytiatr. Phytopharm., 12, 141-146.

BLOCH, G. AND wOOL, D. 1994. Methidation resistance in sweetpotato whitefly (Aleyrodidae: Homoptera) in Israel: selection, heritability and correlated changes of esterases activity. J. Econ. Entomol., 87, 1147-1156.

BOURGUET, D., GENISSEL, A. AND RAYMOND, M. 2000. Insecticide resistance and dominance levels. J. Econ. Entomol., 93, $1588-1595$.

BOUVIER, J. C., BROSSE, V. AND SAUPHANOR, B. 1995. La résistance du carpocapse. L'Arboriculture Fruitière, 479, 21-23.

BOUVIER, J. C., CUANY, A., MONIER, C., BROSSE, V. ET AL. 1998. Enzymatic diagnosis of resistance to deltamethrin in 
diapausing larvae of the codling moth, Cydia pomonella (L.). Arch. Insect Biochem. Physiol., 39, 55-64.

BRUN-BARAle, A., BOUVIER, J. C., PAURON, D., BERGÉ, J. B. AND SAUPHANOR, B. 2000. Involvement of voltage-dependent sodium channels in deltamethrin resistance in a strain of Cydia pomonella. Abstracts of XXXI Int. Congr. Entomol. (Brazil, August 20-26), p. 329.

BURGERJON, A. 1956. Pulvérisation et poudrage au laboratoire par des préparations pathogènes insecticides. Ann. Epiphyt., 7, 675-683.

CURTIS, C. F., COOK, L. M. AND wOOD, R. J. 1978. Selection for and against insecticide resistance and possible methods of inhibiting the evolution of resistance in mosquitoes. Ecol. Entomol., 3, 273-287.

DALY, J. C. AND FISK, J. H. 1992. Inheritance in metabolic resistance to the synthetic pyrethroids in Australian Helicoverpa armigera (Hübner) (Lepidoptera: Noctuidae). Bull. Entomol. Res., 82, 5-12.

DE SOUSA, G., CUANY, A., BRUN, A., AMICHOT, M. ET AL. 1995. A microfluorometric method for measuring Ethoxycoumarin-O-Deethylase activity on individual Drosophila melanogaster abdomens: interest for screening resistance in insect populations. Analyt. Biochem., 229, 86-91.

DENHOLM, I., ROWLAND , M. W., FARNHAM, A. W. AND SAWICKI, R. M. 1990. Laboratory evaluation and empirical modelling of resistance-countering strategies. In: Pesticide Resistance: Strategies and Tactics for Management, pp. 92-104. National Academy Press, Washington, DC.

DEVONSHIRE, A. L. AND FIELD, L. M. M. 1991. Gene amplification and insecticide resistance. Ann. Rev. Entomol., 36, 1-23.

FINNEY, D. J. 1971. Probit Analysis, 3rd edn. Cambridge University Press, Cambridge.

GEORGHIOU, G. P. AND TAYLOR, C. E. 1986. Factors influencing the evolution of resistance. In: Pesticide Resistance: Strategies and Tactics for Management, pp. 157-169. National Academy Press, Washington, DC.

GUENNELON, G., AUDEMARD, H., FREMOND, J. C. AND IDRISSI AMMARI, M. A. 1981. Progrès réalisés dans l'élevage permanent du carpocapse (Laspeyresia pomonella L.) sur milieu artificiel. Agronomie, 1, 59-64.

HALLIDAY, W. R. AND GEORGHIOU, G. P. 1985. Inheritance of resistance to permethrin and DDT in the southern house mosquito (Diptera: Culicidae). J. Econ. Entomol., 78, 762-767.

HOY, M. A., KNOP, N. F. AND JOOS, J. L. 1980. Pyrethroid resistance persists in spider mite predator. Calif. Agric., 34, 11-12.

LANDE, R. 1981. The number of genes contributing to quantitative variation between and within populations. Genetics, 99, 541-553.

MCDONALD, P. T. AND SCHMIDT, C. D. 1987. Genetics of permethrin resistance in the horn fly (Diptera: Muscidae). J. Econ. Entomol., 80, 433-437.

MCKENZIE, J. A. AND BATTERHAM, P. 1994. The genetic, molecular and phenotypic consequences of selection for insecticide resistance. Trends Ecol. Evol., 9, 166-169.

MCNAIR, M. R. 1991. Why the evolution of resistance to anthropogenic toxins normally involves major gene changes: the limits to natural selection. Genetica, 84, 213-219.
PAYNE, G. T., BLENK, R. G. AND BROWN, T. M. 1988. Inheritance of permethrin resistance in the tobacco budworm (Lepidoptera: Noctuidae). J. Econ. Entomol., 81, 65-73.

PLAPP, F. W. 1976. Biochemical genetics of insecticide resistance. Ann. Rev. Entomol., 21, 179-197.

RAYMOND, M. 1985. Présentation d'un programme basic d'analyse log-probit pour micro-ordinateur. Cah. O.R.S.T.O.M., sér. Ent. méd. et Parasitol., 23, 117-121.

RAYMOND, M., PASTEUR, N. AND GEORGHIOU, P. 1987. Inheritance of chlorpyriphos resistance in Culex pipiens L. (Diptera: Culicidae) and estimation of the number of genes involved. Heredity, 58, 351-356.

ROUSH, R. T. AND DALY, J. C. 1990. The role of population genetics in resistance research and management. In: Roush, R. T. and Tabashnik, B. E. (eds) Pesticide Resistance in Arthropods, pp. 97-152. Chapman and Hall, London.

ROUSH, R. T. AND HOY, M. A. 1981. Laboratory, glasshouse, and field studies of artificial selected carbaryl resistance in Metaseiulus occidentalis. J. Econ. Entomol., 74, 142-147.

ROUSH, R. T. AND MCKENZIE, J. A. 1987. Ecological genetics of insecticide and acaricide resistance. Ann. Rev. Entomol., 32, 361-380.

ROUSH, R. T., COMBS, R. L., RANDOLPH, T. C., MACDONALD, J. $E T A L$. 1986. Inheritance and effective dominance of pyrethroid resistance in the horn fly (Diptera. Muscidae). J. Econ. Entomol., 79, 1178-1182.

SAUPHANOR, B., BOUVIER, J. C. AND BROSSE, v. 1998a. Spectrum of insecticide resistance in Cydia pomonella (Lepidoptera. Tortricidae) Southeastern France. J. Econ. Entomol., 91, 1225-1231.

SAUPHANOR, B., BROSSE, V., MONIER, C. AND BOUVIER, J. C. 1998b. Differential ovicidal and larvicidal resistance to benzoylureas in the codling moth, Cydia pomonella. Entomol. Exp. Appl., 88, 247-253.

SAUPHANOR, B., CUANY, A., BOUVIER, J. C., BRoSSE, V. ET AL. 1997. Mechanism of resistance to deltamethrin in Cydia pomonella (L.) (Lepidoptera: Tortricidae). Pestic. Biochem. Physiol., 58, 109-117.

SCOTT, M., DIWELL, K. AND MCKENZIE, J. A. 2000. Dieldrin resistance in Lucilia cuprina (the Australian sheep blowfly): chance, selection and response. Heredity, 84, 599-604.

STONE, B. F. 1968. A formula for determining degree of dominance in cases of monofactorial inheritance of resistance to chemicals. Bull. World Health Org., 38, 325-326.

SVED, J. A. AND MAYO, O. 1970. The evolution of dominance. In: Kojima, K. I. (ed.) Mathematical Topics in Population Genetics, pp. 289-316. Springer, Berlin.

TABASHNIK, B. E., SCHWARTZ, J. M., FINSON, N. AND JOHNSON, M. W. 1992. Inheritance of resistance to Bacillus thuringiensis in diamondback moth (Lepidoptera: Plutellidae). J. Econ. Entomol., 85, 1046-1055.

WALDNER, w. 1993. Rückblick und Vorschau auf die Bekämpfung des Apfelwicklers. Obstbau-Weinbau, 12, 355-357.

WILliAMSON, M. S., MARTINEZ-TORRES, D., HICK, C. A. AND DEVONSHIRE, A. L. 1996. Identification of mutations in the housefly para-type sodium channel gene associated with knockdown resistance $(k d r)$ to pyrethroid insecticides. Mol. Gen. Genet., 252, 51-60. 